\title{
Initiating Global Civil Society as a Strategy for Handling the COVID-19 Public Health Threat: A Policy Review
}

\author{
Dumilah Ayuningtyas ${ }^{*}$, Hayyan U1 Haq ${ }^{2}$, Raden Roro Mega Utami ${ }^{1}$
}

1Department of Health Administration and Policy, Faculty of Public Health, Universitas Indonesia, Indonesia
2Department of Business Law, Faculty of Law, Universitas Mataram, West Nusa Tenggara, Indonesia

\begin{abstract}
The spread of coronavirus disease 2019 (COVID-19) has had a serious impact on public health. The speed and extent of its spread have demonstrated a global failure to cultivate awareness and cooperation in response to the threat. Therefore, in order to improve public awareness and the management of public health threats, we propose a strategy to initiate global civil society. Using Walt and Gilson's policy triangle framework for policy analysis, we reviewed and analysed a series of articles and policies related to COVID-19, severe acute respiratory syndrome coronavirus 2 (SARS-CoV-2), the Global Health Security Agenda (GHSA), health resilience in the context of globalization, as well as other countries' experiences. The study also explored constitutional obligations, public health legislation, collaboration of civil society, and policies related to public health, as well as their implementation. Every country has its own public policy strategy for handling COVID-19. One possible solution is to expand the GHSA commitments and bind all countries that have signed the agreement to a single public policy strategy for the handling of COVID-19. The poor handling of the COVID-19 outbreak has demonstrated the need for Indonesia's civil society collaboratively oversee the Indonesia's government's implementation of its constitutional obligations. The government must make public health security a top priority, and collectives of educated individuals with a strong, shared vision must harness the power of non-governmental advocacy.
\end{abstract}

Keywords: constitutional mandatory, COVID-19, global civil society, global health security, state responsibility

\section{Introduction}

The outbreak of coronavirus disease 2019 (COVID19) has caused tremendous fear and has drawn substantial attention all over the world. The World Health Organization (WHO) has tracked the spread and increase in cases of COVID-19 throughout the world: as of May 15, 2020, there are 4,534,952 confirmed cases in more than 200 countries and one cruise ship containing more than 700 passengers. At least 307,159 deaths have been reported. ${ }^{1}$ Undoubtedly, COVID-19 has transformed into a serious threat to public health.

On February 28, 2020, the WHO raised the global risk status of COVID-19 to the highest level. ${ }^{2}$ Previously, the WHO had also classified COVID-19 under Public Health Emergencies of International Concern (PHEIC), which are defined by the International Health Regulations, or IHR (2005), as extraordinary events that could threaten public health throughout the world due to the threat of spreading diseases internationally, and that need a coordinated international response. This response was prompted by the alarming spread of the dis- ease throughout the world. Within 24 hours, the virus had successfully infected nine new countries, including Azerbaijan, Mexico, and New Zealand. ${ }^{3}$ Italy is the most affected country in Europe ever since the number of COVID-19 cases and deaths in Italy jumped in one night. As the number cases has soared in Italy, Iran, and South Korea, it is has become indisputable that the virus has swept the globe.

COVID-19 is a public health threat that knows no national boundaries. ${ }^{4}$ Bill Clinton has characterized globalization as a world without walls. ${ }^{5}$ Tony Blair has said that globalization is inevitable and irresistible.Their claims have now been validated in the context of health. The inability of countries to defend themselves against the threats of infectious diseases such as severe acute respiratory syndrome (SARS), Avian Influenza, Swine Flu, and COVID-19 has demonstrated that the world we live in is indeed one without walls; the global transmission of dangerous illnesses has become inevitable. The establishment of a "global village" has made it such that countries can no longer effectively control the movement of people

Correspondence $^{*}$ : Dumilah Ayuningtyas, Department of Health Administration and Policy, Faculty of Public Health Universitas Indonesia, Lingkar Kampus Baru Street, Depok City, West Java, Indonesia, E-mail: dumilah.ayuningtyas@gmail.com,Phone: +62-8161840446 
across their borders. Kate Galbraith's definition of globalization as "crossing borders"serves as a warning to us: when there are no more "international borders", 6 then the ability to deal with a variety of risks or potential hazards such as the transmission of infectious diseases is absolutely a must-have. ${ }^{7}$

For this reason, it is crucial to find effective strategies to manage the spread of COVID-19. With its high-risk status, anticipating and preventing the spread of COVID19 will necessitate global cooperation, which can only be established by collective consciousness and a shared vision among the world's population. In light of the importance of the global collective consciousness, in this study, we analyse the relationship between COVID-19 and globalization. Moreover, we discuss the views that diseases such as COVID-19 are direct consequences of globalization and that the Global Health Security Agenda (GHSA) must be central in the response to the outbreak. Finally, we consider the effectiveness of institutionalizing collective awareness as a strategy for responding to global health threats.

\section{Method}

We conducted a policy analysis using Walt and Gilson's policy analysis triangle to incorporate context, actors, process, and content concepts in analysing these policies. We reviewed and analysed a series of articles and policies related to COVID-19, SARS-CoV-2, the Global Health Security Agenda (GHSA), national resilience in the context of globalization, as well as other countries' experiences. We focused on collecting secondary sources, data, and information by using keywords such as "COVID-19", "Coronavirus", "SARS-CoV-2", "GHSA", "globalization", "civil society", and "public health".

The framework also allows the analysis of the contextual factors: social, political, and international aspects that influenced the policy. The analysis of the process by which the policy was initiated, formulated, developed, implemented and evaluated, the objectives of the policy and the actors involved in the decision making as well as constitutional obligations, public health legislation, collaboration of civil society, and policies related to public health, as well as their implementation in the context of COVID-19 was also conducted. To ensure the validity, we included only the most current data, and we conducted extensive literature reviews.

\section{Result and Discussion}

Coronavirus is a family of viruses that cause diseases ranging from the common cold to more severe illnesses such as Middle East respiratory syndrome-related coronavirus (MERS-CoV) and severe acute respiratory syndrome-related coronavirus (SARS-CoV). The SARS-
CoV-2 is a new strain that has been identified in humans. Common symptoms in infected individuals are fever, coughing, shortness of breath, and difficulty breathing. In more severe cases, an infection can cause pneumonia, severe acute respiratory syndrome, kidney failure, or death. 8

On December 31, 2019, the WHO received the first report of SARS-CoV-2 in Wuhan City, the capital city of Hubei Province, People's Republic of China, ${ }^{9}$ which is the seventh largest port city in mainland China. The city is known as one of the centres of the steel industry, a mainstay of China's national infrastructure, and is inhabited by 11 million people. The strategic significance of Wuhan City to China's (and perhaps even the world's) economy made officials reluctant to make public the outbreak of COVID-19. This may explain why COVID-19 incubates and spreads quickly in cities and why it has become a deadly pandemic throughout the world. ${ }^{10,11}$

The increasing global movement of people has brought with it an increased risk of spreading infectious diseases. Indonesia has signed on to several international trade agreements such as General Agreement on Tariffs and Trade (GATT), Trade-Related Investment Measures (TRIMs), Trade-Related Aspects of Intellectual Property Rights (TRIPs), ASEAN Free Trade Area (AFTA), and Free Trade Agreements (FTAs). These agreements have accelerated the improvement and intensity of interaction among people and institutions in various fields, such as socio-economic, trade and investment, and socio-cultural activities. This interaction has increased the dependency of people, institutions, corporations, and nations on one another. Although the government enjoys the economic benefits of such interrelations, it must also possess the capacity to anticipate and overcome the negative impacts of these relationships, such as the transmission of COVID-19.

Undoubtedly, COVID-19 is a global public health issue that requires a coherent strategic response; that is prevention and treatment must occur not only at the macro level, globally, but also regionally, nationally, and even locally. One option is to expand the GHSA commitments, which would oblige all countries that have signed the agreement to develop procedures for preventing, detecting, and responding to public health threats. ${ }^{12}$ At a world health meeting, Frenk J and Gómez-Dantés O,13 suggested that efforts to improve health are universal global activities. Therefore, the pursuance of international initiatives must consider the welfare of all people and embody an ethos of "exchange, evidence, and empathy". Regarding "exchange", countries must be prepared to exchange information on public health risks such as COVID-19. Regarding "evidence", public policy must be informed by data and scientific evidence. Regarding "empathy", interactions between people ought to take place 
according to the principles of humanism. It is necessary to convey priorities in Indonesia. One of them is the participation and empowerment of civil society in each country. ${ }^{13}$

The COVID-19 has spread to more than 200 countries, including Indonesia, and therefore global cooperation is imperative. This is the high price of globalization. The purpose of the GHSA is to respond to the increasing vulnerability of the global community to new diseases and pandemics caused by the negative impacts of climate change, increased trade, movement of humans and other animals across borders, as well as farming practices and industries that are no longer considered acceptable. The GHSA is made up of countries, international organizations, non-governmental organizations, and people in the private sector that want to decrease the threat posed to the world by infectious diseases. Under the leadership of the GHSA, every signed country or party should havea strong commitment to improve global health security and to make it a high priority for world leaders. ${ }^{12}$

The global trend toward a world without boundaries has changed the landscape of interaction between countries, which brings many opportunities and benefits, and has also introduced global threats that should be addressed by global strategies. This is because, regardless of a country's preparedness to face a pandemic, there is still a potential risk to public health. Threats, due to the effects of globalization, cannot be handled by individual countries. It is concerning that the Indonesian government has left the responsibility for handling COVID-19 to the governors, mayors, and heads of sub-districts, as this has resulted in diametric decisions at different levels of government. For example, Ganjar Pranowo, Governor of Central Java Province, and Rismaharini, Mayor of Surabaya City, refused entry to several cruise ships such as Viking Sun, Columbia, Viking Orion, and MS Albatros, while I Wayan Koster, Governor of Bali Province, and Zulkieflimansyah, Governor of NTB Province, announced that they would permit the entry of those cruise ships.

After having reviewed the diametric responses of the central and local governments, we take a critical position on the absence of coordination between them. Constitutionally, the government should be bound to respond consistently to outbreaks such as COVID-19. Some governments consider economic reasons while others underline the importance of public health and safety. Therefore, it is imperative that all governments make their public policies consistent at the local, national, regional, and global levels. It is crucial for the government to initiate and improve cooperation with other countries in order to formulate a consistent global strategy for dealing with outbreaks like COVID-19. This can be embodied by a global agreement that would regulate the proce- dures pertaining to prevention of the spread of COVID19 , treatment of those infected with the disease, as well as the preparation of testing and treatment facilities, such as hospitals and clinics. Now is the time to determine whether or not the GHSA can effectively prevent, detect, and respond to COVID-19. ${ }^{14}$

As members of the GHSA, Indonesia and other countries can initiate the global consciousness needed to deal with the threat of the COVID-19 outbreak. This consciousness is based on Articles 3 and 25 of the Universal Declaration of Human Rights (UDHR), which states "that the state guarantees the life of every human being, guarantees his safety, health and the environment. ${ }^{15}$ In the 1945 State Constitution of the Republic of Indonesia (UUD '45), Article 28 also states that every person has the right to live in prosperity, physically and mentally, and to have a good and healthy environment. ${ }^{16}$ Article 15-1 of the European Convention on Human Rights (ECHR) also confirms the same thing. This means that every country that has signed the UDHR, the ECHR, and other international conventions on health, has a responsibility to enforce policies that protect the health and safety of their citizens.

The above normative foundation stipulates a constitutional obligation of the government in guaranteeing public health. In this respect, the government should make any information that is relevant to citizens' health and safety available to them (Article 28, Indonesian Constitution 1945). Therefore, the government should be informing the public transparently, objectively, rationally and wisely. This would have been instrumental in anticipating public policy blunders in the early stages of the COVID-19 outbreaks, long before a positive case of the disease was found in Indonesia.

The WHO warned of the magnitude of the risk of the pandemic and advised countries not to be overconfident. ${ }^{17}$ Many foreign researchers cynically and critically stated that the absence of COVID-19 in Indonesia was concluded based on 136 tests from 270 million people. ${ }^{18,19}$ When the first COVID-19 case was announced in December 2019, Indonesia had had plenty of time to prepare for the negative impacts of COVID-19 on various government sectors. The government repeatedly claimed that there were no case of COVID-19 in Indonesia, even though the WHO had advised official stopay careful attention to their handling of the spread of the disease. Despite the warnings, the result was confusion, the dissemination of unclear information, and inconsistent public policy. Instead of urging vigilance, the government tried to minimize the apparent scale of the problem and called on the public to be calm in response to the COVID-19 pandemic. ${ }^{20}$ According to the Indonesian community, the government's statement showed a lack of empathy and transparency. The Indonesia's president 
finally appointed a special spokesperson to talk about COVID-19. This authority was left to the Secretary of the Directorate General of Disease Prevention and Control. ${ }^{21}$

Recently, the government introduced public policy intended to anticipate the negative economic impacts of COVID-19. It consists in reducing airplane ticket costs in order to maximize revenue, as well as promoting tourism activities. The Indonesian Minister of Finance has stated that the government has prepared incentives of more than IDR 400 billion to reduce the price of airplane tickets to tourist destinations. The government is also preparing subsidies for local governments in the form of grants of more than IDR 3 trillion for hotel and restaurant tax exemptions for entrepreneurs, including IDR 72 billion for social media influencers promoting tourist destinations in Indonesia (familiarization trip). ${ }^{22}$ This policy is different from neighbouring countries' policies in Singapore, Korea, and Malaysia, which have put in place a series of policies for preventing the spread of COVID-19, such as informing the public about collective responsibility and cancelling flights to and from Singapore.

Unsurprisingly, the Indonesian government's tourism policy has drawn heavy criticism from the public. The policy has demonstrated that the government's efforts to deal with COVID-19 are not serious enough to stop its spread. Even though Indonesia announced two positive cases of COVID-19 on March 2, 2020, the government stated that it would not reconsider the tourism policy, based on its calculations. The government wants the COVID-19 situation to be resolved without disrupting the country's economy. ${ }^{18}$ Finally, on March 3, 2020, the Minister of Tourism and Creative Economy of Indonesia stated that the provision of incentives for tourism would be postponed indefinitely due to the presence of COVID19 in Indonesia. 23

\section{Conclusion}

In civil society, citizens cooperate voluntarily for mutual benefit, which is crucial for personal development, establishing trust between groups, and making social services accessible. However, civil society remains bound by the rule of law. A social movement is a collective action undertaken by groups in civil society. In dealing with COVID-19, civil society must play an active role.

The public needs to oversee the fulfillment of the government's constitutional obligations as the bearers of the constitutional mandate, and also ensure that they can be held constitutionally responsible. With a shared goal to protect the world from various global health threats, civil society must be positioned as a subject, and not just as an object. Well educated members of civil society can understand what threatens their health and take the neces- sary steps to deal with those threats. Society will be impacted by COVID-19.

The handling of the COVID-19 outbreak requires the coordination of national governments, international organizations, and civil society. The community will be most impacted and thus needs to play an active role in handling this situation. Collaboration between members of civil society, particularly well educated citizens, can help oversee the government's implementation of its constitutional obligations. The Government of Indonesia needs to make public health security a top priority in every policy implementation. One way would be to implement the GHSA in every aspect of public health. Groups of educated people with a strong, shared vision must harness the power of non-governmental advocacy. Protecting the health of the Indonesian people constitutes one aspect of the 1945 Constitution, which is the most fundamental norm in Indonesia.

\begin{abstract}
Abbreviations
COVID-19: Coronavirus Diseases 2019; PHEIC: Public Health Emergencies of International Concern; IHR: International Health Regulations; SARS COV-2: Severe Acute Respiratory Syndrome Coronavirus 2; GHSA: Global Health Security Agenda; WHO: World Health Organization; PPE: personal protective equipment; UNICEF: United Nations Children's Fund; BPS: Badan Pusat Statistik; MERSCoV: Middle East Respiratory Syndrome-related Coronavirus; GATT: General Agreement on Tariffs and Trade; TRIMs: Trade-Related Investment Measures; TRIPs: Trade-Related Aspects of Intellectual Property Rights; AFTA: ASEAN Free Trade Area; FTAs: Free Trade Agreements; UDHR: Universal Declaration of Human Rights; ECHR: European Convention on Human Rights.
\end{abstract}

Ethics Approval and Consent to Participate

Not Applicable

\section{Competing Interest}

Authors declare that they have no competing interests to disclose.

\section{Availability of Data and Materials}

Not Applicable

\section{Authors' Contribution}

Dumilah Ayuningtyas conceived of the presented main idea and developed the theory, and encouraged Hayyan Ul Haq and Raden Roro Mega Utami to investigate and supervised the findings of the work. All authors discussed the results and contributed to the final manuscript. All authors agreed to be personally accountable for their own contributions and ensured that questions related to the accuracy or integrity of any part of the work are appropriately investigated, resolved, and the resolution documented in the literature.

\section{Acknowledgment}

Not Applicable 


\section{References}

1. COVID-19 dashboard: Coronavirus COVID-19 global case. Johns Hopkins University: Center for Systems Science and Engineering (CSSE); 2020.

2. Sembiring LJ. Gawat! WHO naikkan status risiko corona ke level tertinggi. CNBC Indonesia; 2020.

3. Berlinger J. Coronavirus has now spread to every continent except Antarctica. CNN; 2020.

4. Bloomberg. The coronavirus knows no borders, says world health organization. 2020.

5. Clinton WJ. Transcript of Bill Clinton at UC Berkley January 29, 2002. Campus New; 2002.

6. Galbraith J K. Globalisation: making sense of an integrating world. London: The Economist in association with Profile Books; 2007.

7. Ikatan Ahli Kesehatan Masyarakat Indonesia. Globalisasi dan transfer risiko penyakit: tinjauan dan rekomendasi IAKMI terkait kasus penumonia akibat 2019-NCOV. Siaran Pers / Pernyataan Sikap PP IAKMI Terkait 2019-NCOV. November 2014: 15-6.

8. World Health Organization. Coronavirus; 2020.

9. World Health Organization. Novel Coronavirus (2019-nCoV). WHO Bulletin; 2020.

10. BBC News. Wuhan: the London-sized city where the virus began. BBC; 2020.

11. World Health Organization. Report of the WHO-China joint mission on coronavirus disease 2019 (COVID-19); February 16-24, 2020.
12. Global Health Security Agenda. About the GHSA.

13. Frenk J, Gómez-Dantés O. Globalisation and the challenges to health systems. British Medical Journal. 2002; 325 (7355): 95-7.

14. Chattu VK, Kevany S. The need for health diplomacy in health security operations. Health Promotion Perspectives. 2019; 9 (3): 161-3.

15. Zandy J. Universal declaration of human rights. Radical Teacher. 2019; 113: 54-5.

16. Presiden Republik Indonesia. Perubahan kedua Undang-Undang Dasar Negara Republik Indonesia Tahun 1945. 2000; 3: 1-6.

17. Lovelace B. WHO warns failure to prepare for coronavirus now 'could be a fatal mistake. CNBC; 2020.

18. McVeigh $\mathrm{K}$ and Harrison EG. Academic stands by research querying Indonesia's claim to be coronavirus-free. The Guardian; 2020.

19. Bevege A. Is Bali really safe from coronavirus? why Indonesia's claim that no one there has caught the deadly virus could be a complete lie. Daily Mail Australia; 2020.

20. Satria JN. Minta masyarakat Tak panik soal penyebaran virus corona, menkes: enjoy saja. detiknews; 2020.

21. Tim detikcom. Saat Menkes Terawan tak lagi bicara virus corona. detiknews; March 3, 2020.

22. Ananda A. Jurus Jokowi lawan virus corona dengan diskon tiket pesawat. CNN Indonesia; 2020

23. Egeham L. Menteri Wishnutama tunda pemberian insentif pariwisata, termasuk untuk influencer. Liputan6; 2020. 